\title{
Polymeric approach to combat drug-resistant methicillin-resistant Staphylococcus aureus
}

\author{
Shreya Kanth ${ }^{1}$, Akshatha Nagaraja ${ }^{1}$, and Yashoda Malgar Puttaiahgowda ${ }^{1, \star}$ \\ ${ }^{1}$ Department of Chemistry, Manipal Institute of Technology, Manipal Academy of Higher Education, Manipal 576104, India
}

Received: 14 September 2020

Accepted: 3 January 2021

Published online:

25 January 2021

(C) The Author(s) 2021. This article is an open access publication

\begin{abstract}
The current global death rate has threatened humans due to increase in deadly unknown infections caused by pathogenic microorganisms. On the contrary, the emergence of multidrug-resistant bacteria is also increasing which is leading to elevated lethality rate worldwide. Development of drug-resistant bacteria has become one of the daunting global challenges due to failure in approaching to combat against them. Methicillin-resistant Staphylococcus aureus (MRSA) is one of those drug-resistant bacteria which has led to increase in global mortality rate causing various lethal infections. Polymer synthesis can be one of the significant approaches to combat MRSA by fabricating polymeric coatings to prevent the spread of infections. This review provides last decade information in the development of various polymers against MRSA.
\end{abstract}

Handling Editor: Maude Jimenez.

Address correspondence to E-mail: yashoda.mp@manipal.edu 


\section{GRAPHICAL ABSTRACT}

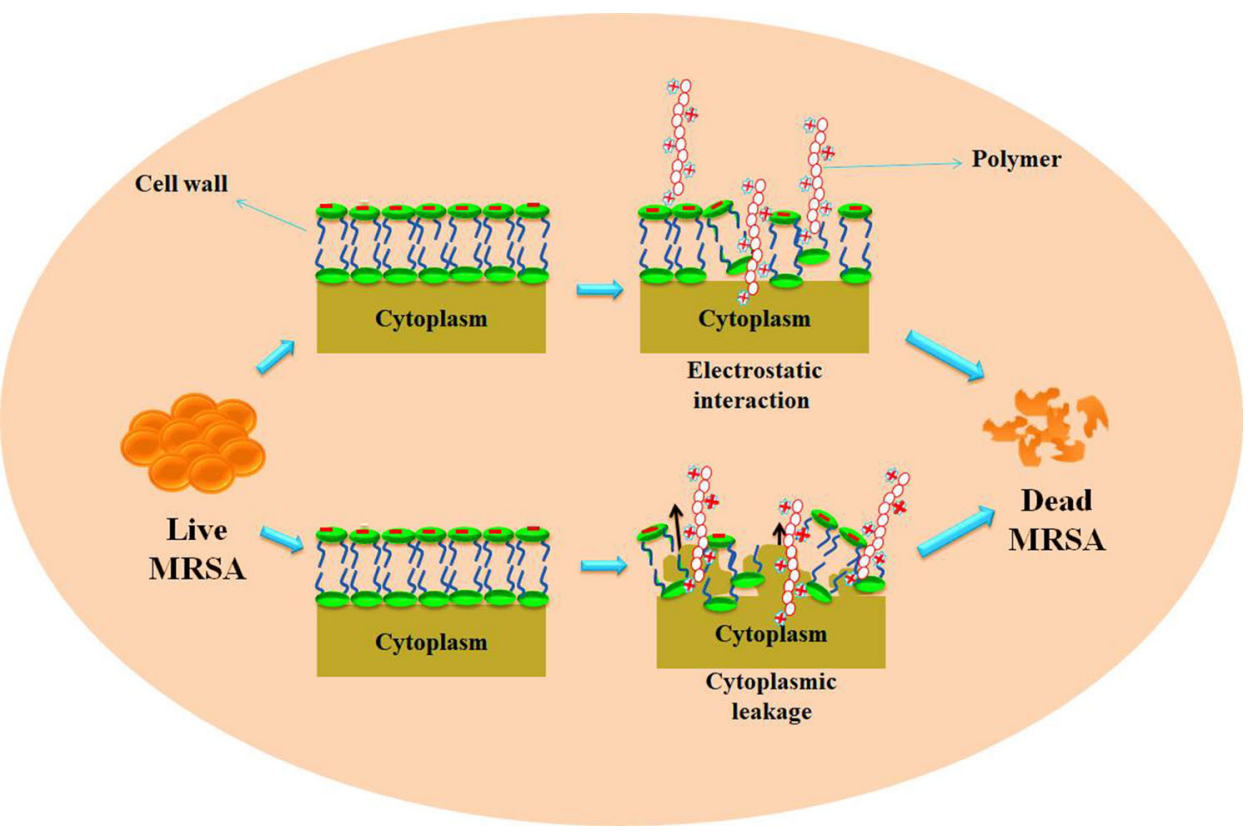

\section{Introduction}

Throughout recent years, biofilm formation and the advent of drug resistance microbes to modern antibiotics have been a significant problem in the area of biomedical science [1-6]. One-quarter of deaths occur worldwide due to microbial infections, particularly in developing countries [7-10]. As per the data reported by US Centers for Disease Control and Prevention, millions of people are infected with antibiotic-resistant bacteria [11, 12]. Since 1980, the number of hospital-acquired infections (HAIs) has increased steadily worldwide, due to rise and spread of multidrug-resistant (MDR) bacteria [13]. MDR is defined as the resistance or insensitivity of microorganisms to the antimicrobial drugs enforced [14]. MDR is recognized as the major cause for the emergence of public health problems [15]. The microorganisms which are resistant to drugs are termed as ESKAPE pathogens [16]. These ESKAPE pathogens comprise both gram-positive and gram-negative species (Enterococcus faecium, Staphylococcus aureus, Klebsiella pneumoniae, Acinetobacter baumannii,
Pseudomonas aeruginosa and Enterobacter species), and these species are responsible for the spread of nosocomial infections and HAIs worldwide [17, 18]. Few most important pathogens which cause HAIs are vancomycin-resistant Enterococcus spp. (VRE), Clostridium difficile, A. baumannii, methicillin-resistant S. aureus (MRSA), P. aeruginosa and Enterobacteriaceae strains [13, 19-22]. Pathogens such as Candida species, viruses [influenza, hepatitis B viruses, adenoviruses, parainfluenza, noroviruses, rotaviruses and severe acute respiratory syndrome (SARS)-associated coronaviruses] also survive on medical equipments and surfaces, to a lesser extent $[23,24]$.

Many studies have found that $>60 \%$ of HAI's around the world is due to the attachment of different pathogens on fracture fixation devices, medical devices and implants and urinary catheters [13, 25-30]. Therefore, there is a necessity to fight against the spreading of MDR.

Among these pathogens, numerous infectious diseases, namely purulent meningitis, pleuritis, pneumonia, tympanitis and bloodstream infections, are caused by gram-positive methicillin-resistant $S$. aureus (MRSA) [31, 32]. Methicillin-resistant S. aureus 
(MRSA) pathogen is a major cause for nosocomial and community infections throughout the world [33]. It causes severe infections which exhibit notable antibiotic resistance [34, 35]. Infections of the skin caused by invasive pathogens begin when the outer skin is affected due to skin diseases, like atopic dermatitis and injury, such as a burn, and these invasive skin infections are majorly caused by $S$. aureus which includes MRSA [36-39]. Overall mortality rate is leading to $10-30 \%$ due to the treatment failure of MRSA-induced bacteraemia [31, 40]. Due to the increased virulence of epidemic strains the restraint of S. aureus, particularly MRSA is very difficult [36]. Transmission control is concentrated on the prevention of spread of these pathogens by environment (contaminated equipments and surfaces) and healthcare workers (contaminated hands) [41]. A relevant amount of microbes is disrupted by disinfection process, using chemical agents like aldehydes, quaternary ammonium compounds, halogens and alcohols, or heat and radiation [13, 22, 42-46]. Sterilization and disinfection processes and at times aerosols need to be used to clean air to constraint hospital infections [22, 42]. Developing novel antibacterial methods to counter MRSA infections is an urgent need.

In recent years, several polymer-coated antimicrobial surfaces, antimicrobial surfaces and polymerbased antimicrobial hydrogels with several properties are developed to deal with clinical threats [1, 47-52]. Antimicrobial polymers are strong candidates among such antimicrobial materials, because they can successfully kill microbes and help to eliminate such pathogens [31,53]. Such antimicrobial polymers target primarily the microbial membrane and show less tendency to cause the development of resistance [1]. They are used in environments at high risk of contamination, with uses such as self-sterilizing catheter tubes, medical drug coatings, surgical devices and wound dressings [54, 55]. Thus, synthetic polymers are commonly used as a new molecular framework for the development of antimicrobials that are active against drug-resistant bacteria [56-60]. This article focuses on various synthesized polymers and polymeric coatings used against methicillin-resistant S. aureus (MRSA) and their study on mechanism, minimum inhibitory concentration (MIC) or zone of inhibition (ZOI).

\section{Polymers containing quaternary ammonium compounds}

Hydroxypropyltrimethyl ammonium chloride chitosan (HACC) with various degree of substitution $(6 \%, 18 \%$ and $44 \%)$ of quaternary ammonium was prepared by the reaction of chitosan with glycidyl trimethylammonium chloride by Peng et al. in 2010 . Three bacteria responsible for orthopedic implantrelated infections, Staphylococcus epidermidis, methicillin-resistant $S$. aureus and S. aureus, were used to evaluate the antibacterial activity of these synthesized polymers. The cationic group of the synthesized polymers targets the bacterial cell surface which is negatively charged. HACC $(18 \%$ substitution $)$ showed excellent potential to inhibit bacterial growth and biocompatibility with osteogenic cells. Biocompatibility and cytotoxicity were also tested for these polymers [61-63].

A series of amphiphilic and biodegradable, broadspectrum antimicrobial polycarbonates were synthesized by Chin et al. in 2013 by metal-free organocatalytic ring-opening polymerization using (MTC$\mathrm{OCH}_{2} \mathrm{BnCl}$ ) as monomer. The synthesized polycarbonates were further quaternized by post-polymerization quaternization reaction with quaternary ammonium groups of various pendant structure to obtain cationic polymers. The antimicrobial activity of synthesized polycarbonates was tested against $P$. aeruginosa, Escherichia coli and S. aureus and clinically isolated nosocomial microbes such as VRE, C. neoformans, A. baumannii and MRSA. Among the synthesized polycarbonates, polymer pbutyl_20 showed excellent antimicrobial activity and selectivity against clinically isolated drug-resistant microbes (VRE, MRSA and carbapenem resistant A. baumannii). Increase in alkyl chain length and hydrophobicity of the polymer raises its tendency to attach to the lipid membrane which leads to membrane disruption and results in cell death. The mechanism of action was studied by field emission scanning electron microscopy [64-67].

Biodegradable antimicrobial polycarbonates, $\mathrm{pBu}$ tyl-20 and pButyl $_{0.5}$ Benzyl $_{0.5-20}$, containing cationic groups were synthesized by Cheng et al. in 2015. The polycarbonates were synthesized via organocatalytic ring-opening polymerization of benzyl chloridefunctionalized cyclic carbonate monomer. The polymers were further quaternized by $N, N$-dimethylbutylamine and $\mathrm{N}, \mathrm{N}$-dimethylbutylamine $/ \mathrm{N}, \mathrm{N}$ - 
dimethylbenzylamine (1:1 molar ratio) as the cationic groups. These polymers form pores on the plasma membrane which eventually destroys the bacterial cell which was studied by transmission electron microscopy. The authors concluded that the synthesized polymers had a wide range of antimicrobial activity and were used for treating multidrug resistance MRSA infection [40, 64, 68, 69].

Uppu et al. in 2016 synthesized cationic amphiphilic polymers by polymerization of poly-(isobutylene-alt-maleic anhydride) with 3-aminopropyldimethylamine followed by quaternization of the tertiary nitrogen of polymerization product, poly(isobutylene-alt- $N$ - $\left(N^{\prime}, N^{\prime}\right.$-dimethylaminopropylmaleimide). The cyclized hydrophobic side chains attached to the cationic part far from the macromolecule are responsible for the death of bacteria. The obtained polymers showed good antimicrobial activity against S. aureus, MRSA, E. coli and vancomycin resistant E. faecium [70-73].

Li et al. in 2016 synthesized a novel antimicrobial polymer, poly $(N, N$-dimethylaminoethylmethacrylate)-block-poly(L-lacticacid)-block-poly $(N, N$ -

dimethylaminoethylmethacrylate) conjugated with poly(ethylene glycol) (D-PLLA-D@PEG) triblock copolymers by the combination of atom transfer radical polymerization. These polymers were further quaternized with two different chemical compositions (D-PLLA-D@Q 1: 12.3\%; D-PLLA-D@Q 2: $26.2 \%)$. The amphiphilic and cationic groups are present in the polymer targets and rupture the bacterial membrane through electrostatic interaction and infuse into the membrane lipid domains and decrease the resistance of bacteria. All these polymers exhibited good antimicrobial activity against methicillinresistant $S$. aureus. The authors concluded this could be used for coating hospital surfaces, gowns and prevents MDR bacteria [74-77].

Based on cationic polyaspartamide derivatives, four kinds of novel biodegradable antibacterial polymer with various lengths of side chains were synthesized by using $\beta$-benzyl-L-aspartate $N$-carboxy anhydride through ring-opening polymerization by Yan et al. in 2019. The synthesized Q-PAsp (BDA) catiomers showed a wide range of antibacterial activity against gram-negative and gram-positive bacteria. To enhance the biocompatibility of polycations, carboxylatopillar[5]arene (CP[5]A) was introduced to polymeric catiomers. The synthesized polymers attach to the surface of bacteria through electrostatic interaction (between polymer and negatively charged cell membrane) and disturb the normal functioning of bacteria leading to structural destabilization resulting in bacterial cell death. The mechanism was studied by scanning electron microscopy and confocal laser scanning microscopy. The authors concluded Q@CP[5]A exhibited excellent activity against in vivo MRSA and hence could be used for wound healing and inhibit antibiotic-resistant pathogenic bacterium [78-81] (Table 1).

\section{Surface-coated polymers containing quaternary ammonium compounds}

The importance of coating organo-Si quaternary ammonium chloride (QAC) polymer, a JUC spray on surfaces of medical devices to reduce MRSA contamination in hospital environments, was studied by Yuen et al. in 2015. The bactericidal property is exhibited due to the electrostatic force between the positively charged coated surface and negatively charged cell membrane. The authors demonstrate the antimicrobial coating of QAC polymer in addition to hypochlorite wiping on bed units and high-touch surfaces could significantly reduce the contamination rate in hospital wards [82-85] (Table 2).

\section{Polymers without quaternary ammonium compounds}

For hospital infection control, permanent sterile-surface materials were developed by Zhou et al. in 2011. Four guanidine hydrochloride polymers (polyoctamethylene guanidine hydrochloride (POMG) (polymer $\mathrm{C}_{8}$ ), polyhexamethylene guanidine hydrochloride (PHMG) (polymer $\mathrm{C}_{6}$ ), polybutamethylene guanidine hydrochloride (polymer $\mathrm{C}_{4}$ ) and poly $(m$-xylylene methylene guanidine hydrochloride) (polymer $\left.\mathrm{C}_{8 \text { (benzene) }}\right)$ ) were synthesized, and their antimicrobial activity was evaluated against meticillin-resistant $S$. aureus, multidrug-resistant $P$. aeruginosa, coagulase-negative staphylococci, ceftazidime-resistant Citrobacter spp. and Enterobacter spp., vancomycin-resistant E. faecium. PHMG and POMG showed immense and tremendous antimicrobial activity against antibiotic-resistant bacteria which causes nosocomial infections. The probable mechanism is that the antimicrobial activity 
Table 1 List of polymers containing quaternary ammonium compounds synthesized by various authors against MRSA and other pathogenic microorganisms

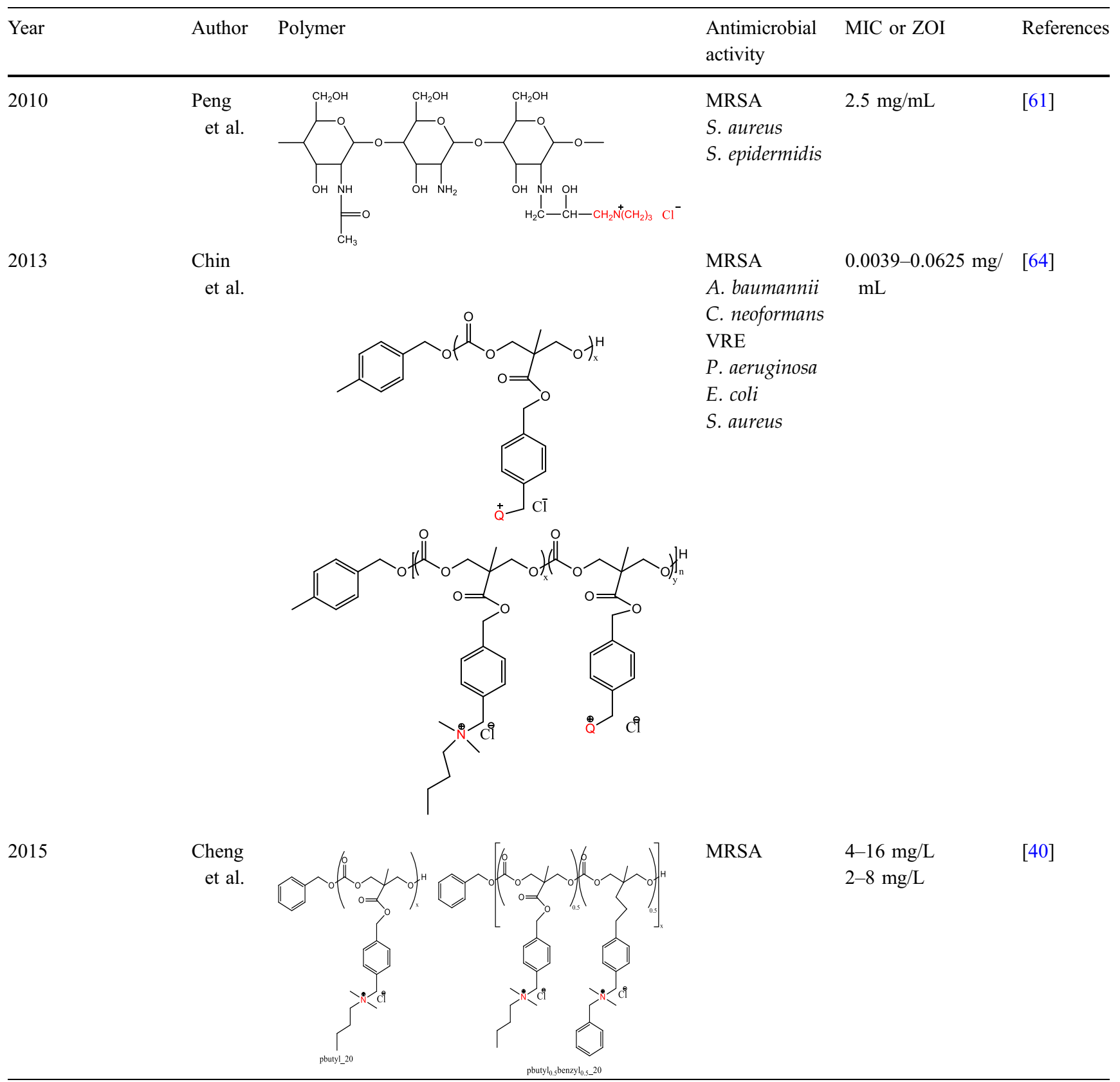


Table 1 continued

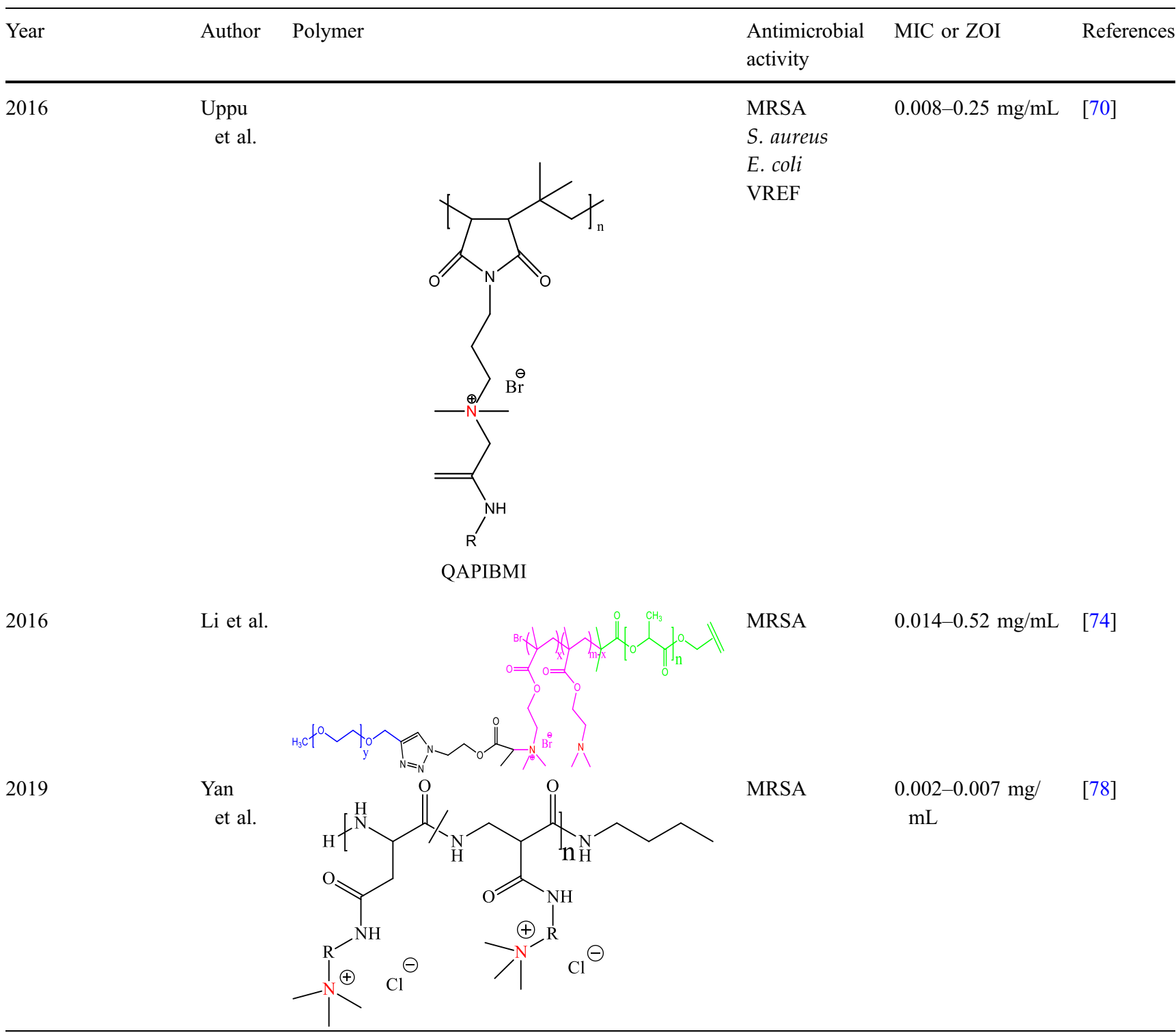

Table 2 List of polymers containing quaternary ammonium compounds for coating against MRSA

\begin{tabular}{llllll}
\hline Year & Author & Polymer & Antimicrobial activity & MIC or ZOI & References \\
\hline 2015 & Yuen et al. & Organo-Si quaternary ammonium chloride (QAC) polymer & MRSA & Not available & {$[82]$} \\
\hline
\end{tabular}

is due to the physicochemical interaction between the bacterial envelop and polymer molecule. The positively charged hydrophobic polymer interacts with the negatively charged phospholipids which damages the cytoplasmic membrane resulting in cell lysis [86-88].
Thoma et al. in 2014 synthesized ammonium ethyl methacrylate homopolymers (AEMPs) with primary ammonium groups in the side chain with various molecular weights $\left(\mathrm{P}_{7.7}, \mathrm{P}_{10}, \mathrm{P}_{12}\right)$ by RAFT polymerization. E. coli, P. aeruginosa, S. saprohyticus, A. baumannii, S. aureus, Bacillus subtilis, Enterococcus faecalis 
and MRSA were used to study the antimicrobial activity of the synthesized polymers. These polymers showed a wide range of activity against gram-positive bacteria including MRSA, than gram-negative bacteria. Probably, the primary ammonium groups present in the side chains of the polymer were the cause for disruption of bacterial cell membrane. This article demonstrates that the synthesized polymers could be used for treatment of topical $S$. aureus infections [56, 89, 90].

For the control of hospital-acquired infections, surface-active, photodynamic antimicrobial polymers incorporated with photosensitizers were prepared by McCoy et al. in 2014 and their antimicrobial activity was tested against MRSA and E. coli. High-density poly(ethylene) (HDPE) were incorporated with various photosensitizers (TMPyP, TPP, TBO and MB) using hot-melt extrusion process, which exhibits antimicrobial activity in the presence of light. HDPE films and HDPE films incorporated with sentisizers were placed on one another and made into a twin layer by platen press. The reactive oxygen species (ROS) generated due to the irradiation of photosensitizers incorporated in the polymer films reacts with the bacterial cell components (lipids, proteins and nucleic acids) and causes cell death. HDPE films incorporated with TMPyP exhibited excellent antimicrobial activity against MRSA in the presence of light [91-93].

Labena et al. in 2016 synthesized hyperbranched poly(amidoamine) (h-PAMAM) with various terminal groups (h-PAMAM-ester, h-PAMAM-amine, h-PAMAM-amine plus) by repeated Michael addition and amidation to enhance reliability of the synthesis. The antimicrobial activity was tested against B. subtilis, Candia albicans, S. aureus, Aspergillus niger, P. aeruginosa, E. coli and MRSA. The electrostatic interactions between the cell membrane and h-PAMAM molecules cause denaturation of membrane's protein and enter into phospholipid layer, which with raise in permeability causes membrane destabilization followed by intracellular structure leakage which leads to bacterial cell death. The authors demonstrated that h-PAMAM with amine terminations (amine and amine plus) showed broadspectrum antimicrobial activity against MRSA [94-97].

A series of amphiphilic, cationic polycarbonate polymers containing primary amino groups (single, diblock and random) was synthesized by
Nimmagadda et al. in 2016, and their antimicrobial activity was tested against three gram-positive bacterial strains vancomycin-resistant E. faecalis (VREF), methicillin-resistant S. aureus (MRSA) and methicillin-resistant S. epidermidis (MRSE). The random polymers exhibited a wide range of antimicrobial activity than single or diblock polymers. The random polymer with 20 hydrophobic and 20 hydrophilic units showed excellent activity against multidrugresistant bacteria (MRSA). The polymer micelle on contact with bacterial surface breaks into small entities due to change in electrostatic interactions. Due to the amphipathic nature of the free polymer chain, it enters through the surface of bacteria which disrupts the bacterial membrane and leads to cell death; the mechanism was studied by TEM $[65,66,98,99]$.

A series of six cationic chitosan derivatives, $\mathrm{N}-(2-$ hydroxypropyl)-3-trimethylammonium chitosan chlorides (HTCC), by changing the mole ratio of glycidyltrimethylammonium chloride (GTMAC) were synthesized by Hoque et al. in 2016. The synthesized cationic polymers on interaction with anionic bacterial membrane disrupt the cell membrane leading to cell death. The mechanism of action was confirmed by several microscopic and spectroscopic methods. The antifungal and antibacterial property of the prepared HTCC polymers was evaluated against drug-sensitive bacteria (A. baumannii, $S$. aureus and E. coli) and MDR bacteria (VRE, MRSA and $\beta$-lactamresistant $K$. pneumonia). Among the synthesized series of derivatives, two active polymers (HTCC3 and HTCC6) showed significant activity against MRSA in a murine model of superficial skin infection [100-103].

In another study, Kamaruzzaman et al. in 2016 found that a cationic polymer, polyhexamethylene biguanide (PHMB), had excellent antimicrobial properties and could be treated against intracellular MRSA (EMRSA-15 and USA 300). PHMB co-localizes with intracellular MRSA in keratinocytes, indicating that killing occurs by direct interactions inside host cells. The authors conclude that PHMB has potential to treat skin infections caused by intracellular MRSA and other intracellular bacteria [36, 104-106].

Hong et al. in 2017 synthesized cationic amphiphilic random methacrylate copolymer $\left(\mathrm{PE}_{31}\right)$ with $\mathrm{pH}$-responsive activity by RAFT polymerization. The mechanism explained is electrostatic interaction occurs between the positively charged polymer and negatively charged cell wall. On interaction, the 
hydrophobic side chains of a polymer enter into hydrophobic portion of bacterial lipid membrane, which causes disruption of membrane leading to bacterial cell death. The authors concluded that the polymer showed high antimicrobial activity against vancomycin-intermediate $S$. aureus and methicillinresistant $S$. aureus at neutral $\mathrm{pH}$ [107-110].

Biocompatible, inexpensive, water-soluble macromolecular antimicrobial polyionenes were developed by Liu et al. in 2017 for the treatment of hospitalacquired and MDR infections. Catalytic-free, polyaddition polymerization process was used for the synthesis of series of antimicrobial polyionenes. Hydrophilic and hydrophobic groups were distributed alternatively in the polymer chain, among which hydrophobic components were in contact with negatively charged cell wall. The hydrophobic components target the lipid bilayer causing cytoplasmic membrane disruption and resulting in cell lysis. The antimicrobial activity of synthesized polymers was examined against MRSA, S. aureus, K. pneumonia, A. bacumanii, C. neoformans, E. coli and C. albicans [59, 111, 112].

An antimicrobial polymer which showed activity against S. aureus, MRSA, MSSA and other HAIs was synthesized by Mercer et al. in 2017. The authors prepared NP 108, a cationic, poly-lysine polymer made up of amino acid building blocks which was water-soluble and had a wide range of antimicrobial activity. The macromolecule shows membrane-acting bactericidal activity due to net positive charge present on the polylysine, which causes disruption of cell membrane resulting in cell death. These polymers were used for nasal delcolonization of $S$. aureus and prevention of HAI [53, 113, 114].

To eradicate multidrug-resistant (MDR) bacterial infections, Chin et al. in 2018 synthesized a biodegradable macromolecule, guanidinium-functionalized polycarbonates. The synthesized polymers (pEt_10 and pEt_20) showed broad-spectrum antimicrobial activity against MDR $P$. aeruginosa, E. coli, A. baumannii, MRSA and K. pneumonia. This polymer also exhibits electrostatic interaction between the polymer and cell wall, and targets cytoplasmic membrane resulting in releasing of cell constituents which leads to cell death. These polymers were less toxic and had great potential for the treatment and prevention of MDR systemic infections [115-118].
Poly(para-phenylene ethynylene) (PPE)-and poly(para-phenylene vinylene) (PPV)-poly[(2-(methacryloyloxy)ethyl)trimethylammonium chloride] (PMETAC) graft copolymers of low and high molecular weights were synthesized by Damavandi et al. in 2018. The cationic side chains present in the conjugated polymers interact with the negatively charged surface of bacterial cell and exhibit antimicrobial activity. The antimicrobial activities of synthesized polymers were tested against MRSA, E. coli, E. faecium and $A$. baumannii. The authors found that the low molecular weight PPE-g-PMETAC copolymer showed significant antimicrobial activity [119-121].

In 2019, Hong et al., studied about novel antimicrobial polyionene, $\operatorname{poly}\left(N, N^{\prime}\right.$-(ethane-1,2-diyl)bis(4(chloromethyl)benzamide)-co-tetramethyl-1,3-diaminopropane), synthesized by Lou et al. in 2018 for the treatment of MRSA-induced bloodstream infection. Antimicrobial polymers form pores on plasma which leads to leakage of cytoplasmic components resulting in cell death. The authors demonstrated that the polymer possessed strong antimicrobial activity against MRSA. Due to negligible toxicity and potential therapeutic effect, the polymer could be used to treat MRSA caused, especially blood stream infections [31, 122, 123].

Electrospun fiber mats were synthesized by Boncu et al. in 2019 for the treatment methicillin-resistant $S$. aureus (MRSA) associated with bone infections and soft tissues. Biodegradable polymers, poly(lactic-coglycolic) acid (PLGA) and polycaprolactone (PCL) loaded with linezolid, were used for preparing electrospun fiber mats. The antibacterial activity of synthesized fiber mats was examined against isolated bacteria (MRSA) which causes prosthetic infections. The fibers were non-toxic, biocompatible, biodegradable and had long-term activity [124-126].

Kuroki et al. in 2019 synthesized series of ammonium and guanidinium polymers of various sequences (statistical, diblock and tetrablock) by RAFT polymerization. The synthesized polymers were tested for antimicrobial activity against MDR methicillin-sensitive strains (MSSA) and methicillinresistant S. aureus (MRSA). The authors concluded that diblock guanidinium (GD30) polymer had major impact for the treatment of intracellular, MDR bacteria (MSSA and MRSA). Here bacterial DNA binding and pore formation both would have occurred, leading to death of bacteria [127-130]. 
For the treatment of MRSA a new method, Antibacterial Photodynamic Therapy (APDT) was used by Guo et al. in 2020, to deliver photosensitizers. In this article self-assembled, lipase sensitive micelle was developed to deliver hydrophobic hypocrellin A (HA). Polymeric micelle made up of methoxy poly(ethylene glycol)-block-poly(e-caprolactone) (mPEGPCL/HA), an amphiphilic copolymer, was used to encapsulate HA. The polymeric micelles could release HA in the presence of lipase, on irradiation of light or in appropriate wavelength range and this improved the APDT activity. These mPEG-PCL/HA micelles showed high activity against MRSA and could be used to combat MRSA infections [131-134].

Christofferson et al. in 2020 synthesized diblock and triblock oligomers by photo-induced atom transfer radical polymerization and studied their antimicrobial activity against gram-positive bacteria namely $S$. aureus and MRSA. In this article, it has been reported that the triblock oligomers showed excellent antibacterial activity $\sim 99 \%$ and $98 \%$ against S. aureus and MRSA compared to the diblock oligomers, because the oligomer systems had conformational differences. The interaction between peptidoglycan functional group leads to the disruption of peptidoglycan layers [135, 136] (Table 3).

\section{Surface-coated polymers without quaternary ammonium compounds}

Antifouling surface coatings were developed with antimicrobial properties on silicon rubber to fight against intravascular catheter-associated infections (CAIs) using diblock copolymers which was synthesized by Ding et al. in 2012. (PEG- $b$-cationic polycarbonates) were synthesized by metal-free organocatalytic ring-opening copolymerization of poly(ethylene glycol) (PEG) and cationic polycarbonate. Polymers coatings were developed using reactive polydopamine (PDA) to increase antimicrobial properties of substrate surface. These properties of the polymeric coatings were systematically investigated against methicillin-resistant $S$. aureus and methicillin-susceptible $S$. aureus, which are the major causes of intravascular catheter-associated infections. The tests were carried out for various polymers compositions. The hydrophobic monomer unit present in the polymer may interact with the bacterial cell membrane by incorporating into the lipid domain and resulting in cell death [137-140].

The efficacy of biodegradable poly-D,L-(lactide) (PDLLA) polymer solution loaded with linezolid antibiotic and coated on orthopedic Kirschner wires (K-wires) by dip coating technique to prevent the adhesion of MRSA was studied by Kaur et al. in 2014. The adherence of MRSA was evaluated on naked wires, PDLLA wires, K1, K2 and K3 wires (PDLLA impregnated with three different concentrations of linezolid $(2.5 \%, 5 \%$ and $10 \%))$. The authors concluded that $\mathrm{K} 2$ and $\mathrm{K} 3$ wires decreased bacterial adhesion by $60 \%$ when compared to $\mathrm{K} 1$ (which decreased by $40 \%)$, PDLLA and naked wires. The reduction in the bacterial attachment on wires was correlated with the amount of drug released from the wires [141-144].

Dinjaski et al. in 2014 studied the antimicrobial properties of poly-3-hydroxy-acetyllthioalkanoate-co3-hydroxyalkanoate (PHACOS) containing thioester groups in the side chains by comparing it with nonreactive poly(3-hydroxyoctanoate-co-hydroxyhexanoate) (PHO) and poly(ethylene terephthalate) (PET). PET disks were coated with PHACOS and PHO by solvent casting, and uncoated PET disks were used as control for examining the antimicrobial activity and bacterial adhesion of $S$. aureus subsp. aureus, Streptococcus pyogenes, Mycobacterium smegmatis, B. subtilis subsp. subtilis, E. coli, S. epidermidis, MRSA, P. aeruginosa and Streptococcus dysgalactiae subsp. equisimilis. The bacterial activity of $S$. aureus on $\mathrm{PHO}$ was more compared to that of PHACOS, which demonstrates that PHACOS possesses anti-staphylococcal activity. In addition to this, PHACOS effectively inhibits the growth of MRSA. This activity is exhibited by functionalized side chains which possess thioester groups. This article concludes that PHACOS acts as contact active surface which decreases the adhesion of $S$. aureus and MRSA, and hence can be used in biomedical implants as an infection-resistant material [110, 145-147].

Polyastaxanthin (p (ATX)) coatings were developed by Weintraub et al. in 2018, and their antimicrobial activity was examined against $S$. aureus (MRSA and MSSA) and S. epedermidis by coating them on polyurethane catheters. Since the polymeric coating material was biodegradable and had excellent antimicrobial properties, authors concluded that the coatings could be used as antimicrobial coating for medical devices [148-150] (Table 4). 


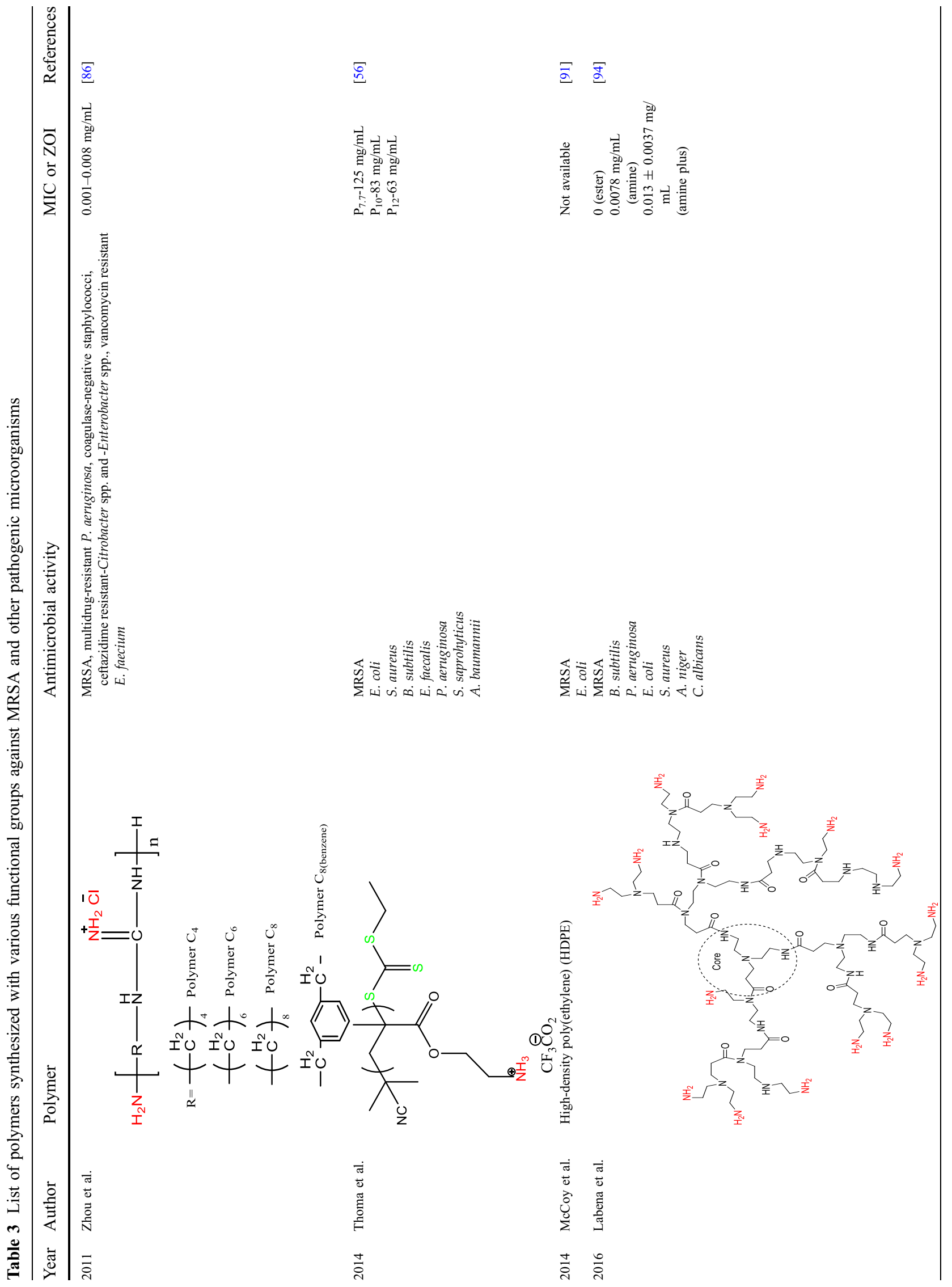




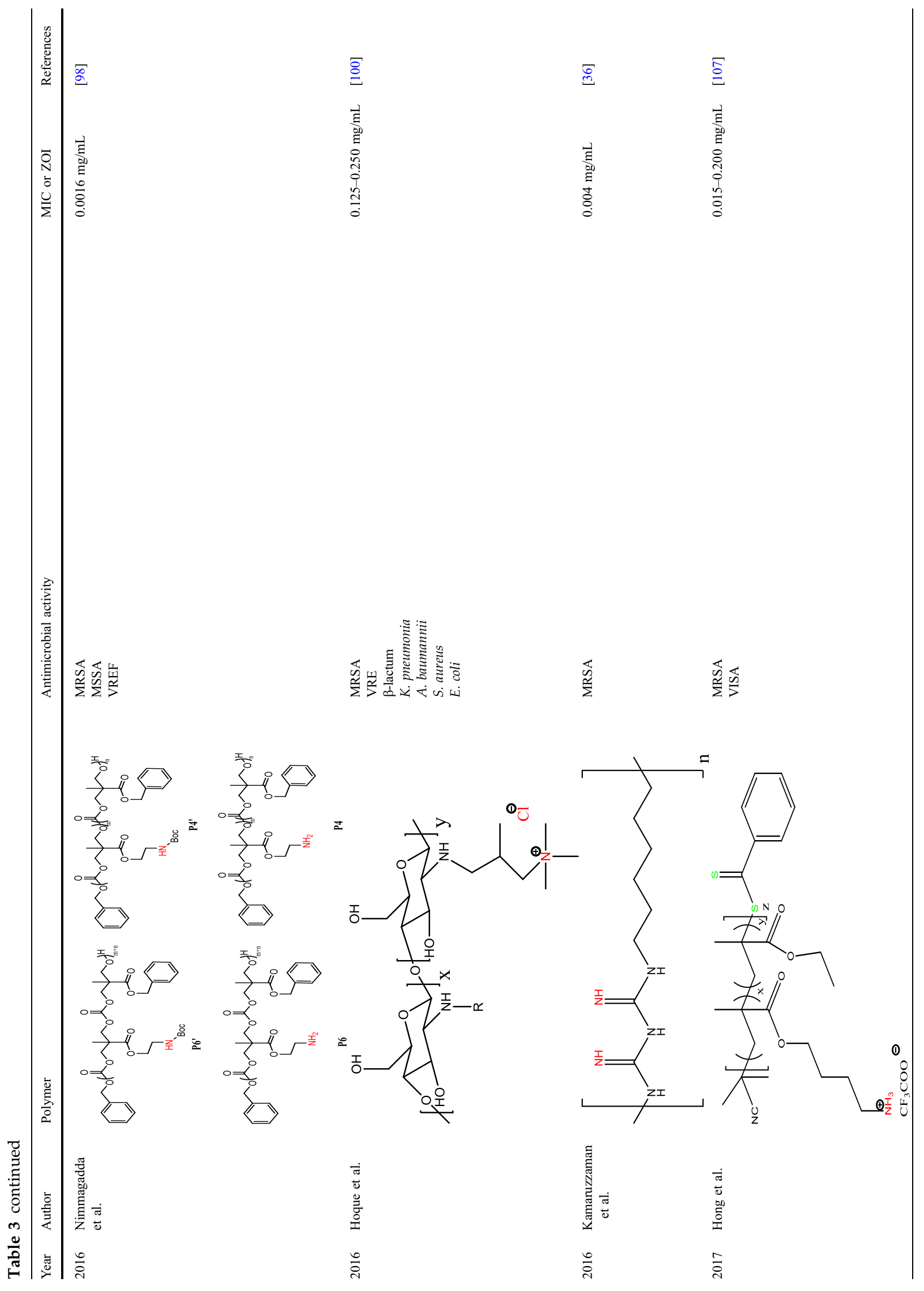




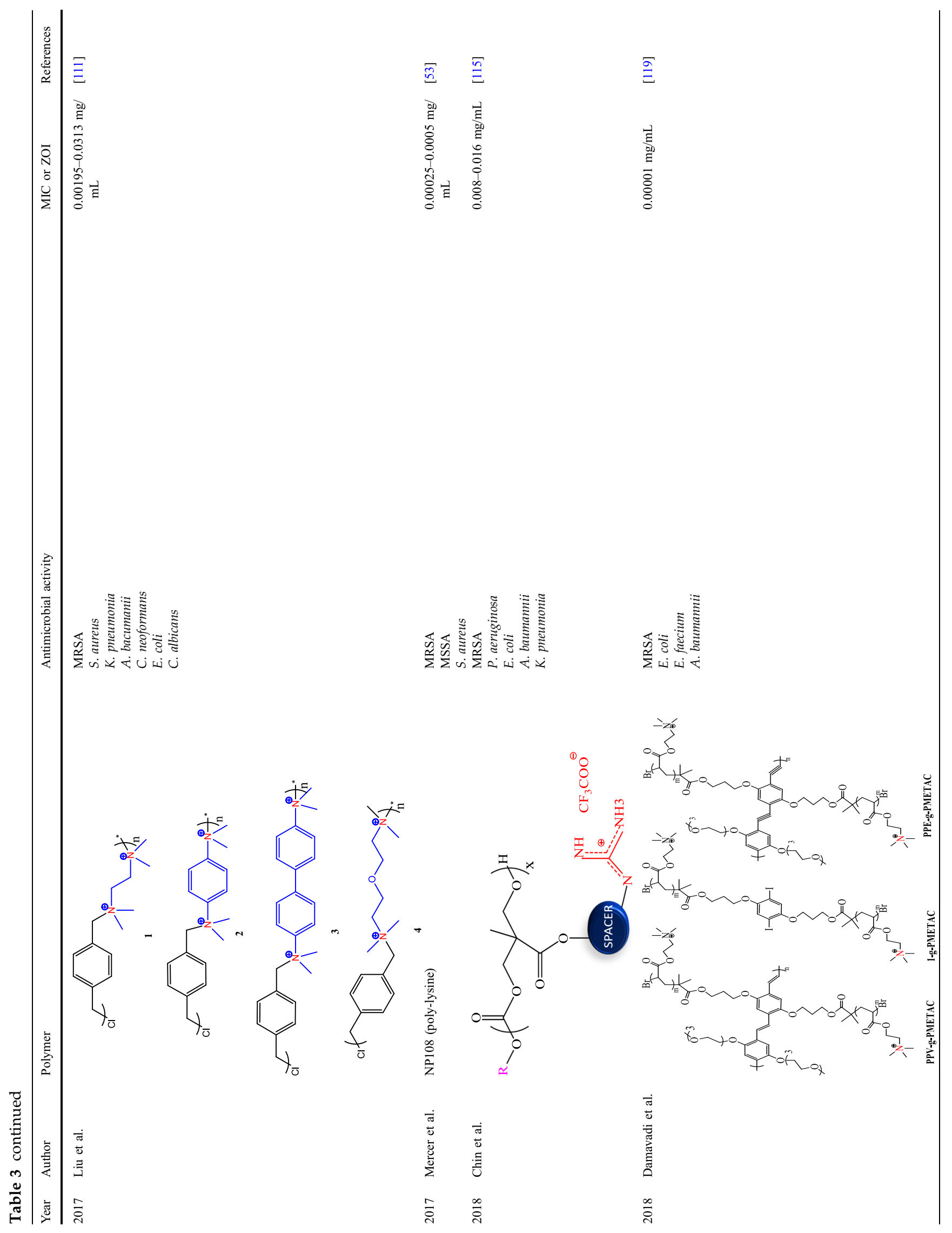




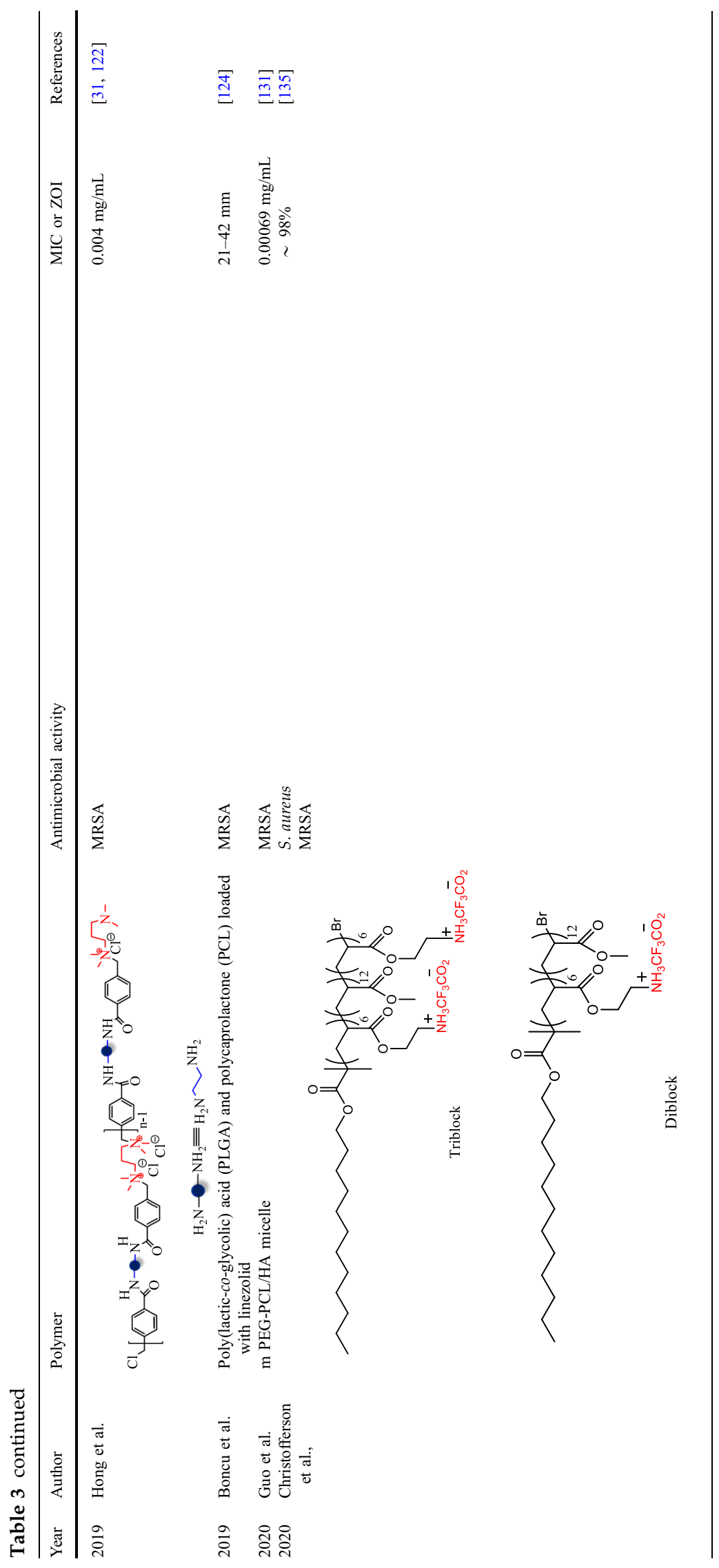


Table 4 List of polymers synthesized with various functional groups for coating against MRSA and other pathogenic microorganisms

\begin{tabular}{|c|c|c|c|c|c|}
\hline Year & Author & Polymer & Antimicrobial activity & $\mathrm{MIC}$ or $\mathrm{ZOI}$ & References \\
\hline 2012 & Ding et al. & & $\begin{array}{l}\text { MRSA } \\
\text { MSSA }\end{array}$ & $1.88 \mathrm{~mm}$ & {$[137]$} \\
\hline 2014 & Kaur et al. & Poly-D,L-(lactide) (PDLLA) polymer & MRSA & $\begin{array}{l}0.002-0.004 \mathrm{mg} / \\
\mathrm{mL}\end{array}$ & {$[141]$} \\
\hline 2014 & $\begin{array}{l}\text { Dinjaski } \\
\text { et al. }\end{array}$ & $\int_{\text {PHACOS }}^{s^{\prime}}=0$ & $\begin{array}{l}\text { MRSA } \\
\text { S. aureus subsp. Aureus } \\
\text { S. pyogenes } \\
\text { M. smegmatis } \\
\text { B. subtilis subsp. Subtilis } \\
\text { E. coli } \\
\text { S. epidermidis } \\
\text { P. aeruginosa } \\
\text { S. dysgalactiae subsp. } \\
\text { equisimilis }\end{array}$ & Not Available & {$[145]$} \\
\hline 2018 & $\begin{array}{l}\text { Weintraub } \\
\text { et al. }\end{array}$ & & $\begin{array}{l}\text { MRSA } \\
\text { MSSA } \\
\text { S. epidermis }\end{array}$ & Not available & {$[148]$} \\
\hline
\end{tabular}

The antimicrobial activity exhibited by the polymers depends on the molecular weight [56, 64, 100, 119, 135], alkyl chain length $[64,70,86,115]$ and terminal functional group [94] of the polymers. The synthesized polymers had various advantages such as biocompatibility and low toxicity and thus were used for several applications such as in biomedical implants, disinfectants for hospital infection control, in orthopedic operations, treatment of nasal colonization infections, skin infections and bloodstream infections. Few polymers were used for coating kirschner wires, polyurethane tubes, etc., to prevent the spread of bacteria. Certain polymers had resistant ability only toward few pathogens, and they had MIC values slightly higher compared to their corresponding standards due to which the application was limited in biomedical field.

\section{Conclusion}

Drug-resistant MRSA which causes numerous deadly infectious diseases, namely tympanitis, pneumonia, purulent meningitis pleuritis and bloodstream infection, can be reduced by the approach toward polymeric synthesis. This article reports the polymers synthesized by various research groups to treat MRSA since last decade. Polymers with various beneficial properties like biocompatibility, stability (thermal and mechanical) and antimicrobial activity were synthesized, and their ability to prevent MRSA has been described. This article also discusses the authors who showed interest in loading antibiotics to polymeric backbones to fight against MRSA. On the whole, the mechanisms explained for various polymers are in two ways (i) electrostatic interaction between polymers and cell wall and (ii) polymers targeting cytoplasmic membrane. Future research in the field of combating MRSA can be focused on polymer surface coatings to restrain the spread of MRSA and other multidrug-resistant bacteria.

\section{Funding}

Open access funding provided by Manipal Academy of Higher Education, Manipal. 
Open Access This article is licensed under a Creative Commons Attribution 4.0 International License, which permits use, sharing, adaptation, distribution and reproduction in any medium or format, as long as you give appropriate credit to the original author(s) and the source, provide a link to the Creative Commons licence, and indicate if changes were made. The images or other third party material in this article are included in the article's Creative Commons licence, unless indicated otherwise in a credit line to the material. If material is not included in the article's Creative Commons licence and your intended use is not permitted by statutory regulation or exceeds the permitted use, you will need to obtain permission directly from the copyright holder. To view a copy of this licence, visit http://creativecommons.org/licen ses/by $/ 4.0 /$.

\section{References}

[1] Konai MM, Bhattacharjee B, Ghosh S, Haldar J (2018) Recent progress in polymer research to tackle infections and antimicrobial resistance. Biomacromol 19:1888-1917. https://doi.org/10.1021/acs.biomac.8b00458

[2] Torgerson CM, Mapp B (2017) Drug-resistant bacteria ranked. Nature. https://doi.org/10.1038/nature.2017.21550

[3] Brown ED, Wright GD (2016) Antibacterial drug discovery in the resistance era. Nature 529:336-343. https://doi.org/ 10.1038/nature17042

[4] Bush K, Courvalin P, Dantas G et al (2011) Tackling antibiotic resistance. Nat Rev Microbiol 9:894-896. http s://doi.org/10.1038/nrmicro2693

[5] Butler MS, Blaskovich MA, Cooper MA (2017) Antibiotics in the clinical pipeline at the end of 2015. J Antibiot (Tokyo) 70:3-24. https://doi.org/10.1038/ja.2016.72

[6] Boucher HW, Talbot GH, Bradley JS et al (2009) Bad bugs, no drugs: no ESKAPE! An update from the Infectious Diseases Society of America. Clin Infect Dis 48:1-12. h ttps://doi.org/10.1086/595011

[7] Nagaraja A, Jalageri MD, Puttaiahgowda YM et al (2019) A review on various maleic anhydride antimicrobial polymers. J Microbiol Methods 163:105650. https://doi.org/10. 1016/j.mimet.2019.105650

[8] Nagaraja A, Puttaiahgowda YM, Kulal A et al (2019) Synthesis, characterization, and fabrication of hydrophilic antimicrobial polymer thin film coatings. Macromol Res 27:301-309. https://doi.org/10.1007/s13233-019-7040-5

[9] Jalageri MD (2019) Synthesis and fabrication of highly functionalized Jeffamine antimicrobial polymeric coating.
Polym Adv Technol 30:1616-1627. https://doi.org/10.100 2/pat.4592

[10] Jalageri MD, Malgar Puttaiahgowda Y, Parambil AM, Kulal A (2019) Design of multifunctionalized piperazine polymer and its activity toward pathogenic microorganisms. J Appl Polym Sci. https://doi.org/10.1002/app.47521

[11] Nagaraja A, Puttaiahgowda YM, Devadiga D (2019) Synthesis and fabrication of high-potent antimicrobial polymeric ultrathin coatings. J Appl Polym Sci 136:1-10. h ttps://doi.org/10.1002/app.47893

[12] Nagaraja A, Manohara Dhulappa Jalageri YMP (2020) A thirst for polymeric antimicrobial surfaces/coatings for diverse applications. In: Engineered antimicrobial surfaces, pp 13-32

[13] Abreu AC, Tavares RR, Borges A et al (2013) Current and emergent strategies for disinfection of hospital environments. J Antimicrob Chemother 68:2718-2732. https://doi. org/10.1093/jac/dkt281

[14] Tanwar J, Das S, Fatima Z, Hameed S (2014) Multidrug resistance: an emerging crisis. Interdiscip Perspect Infect Dis. https://doi.org/10.1155/2014/541340

[15] van Duin D, Paterson DL (2016) Multidrug-resistant bacteria in the community: trends and lessons learned. Infect Dis Clin North Am 30:377-390. https://doi.org/10.1016/j. idc.2016.02.004

[16] Khan SN, Khan AU (2016) Breaking the spell: combating multidrug resistant "superbugs.” Front Microbiol 7:1-11. h ttps://doi.org/10.3389/fmicb.2016.00174

[17] Santajit S, Indrawattana N (2016) Mechanisms of antimicrobial resistance in Pasteurellaceae. PBioMed Res Int 2016:1-8

[18] Rice LB (2010) Progress and challenges in implementing the research on ESKAPE pathogens. Infect Control Hosp Epidemiol 31:S7-S10. https://doi.org/10.1086/655995

[19] Talon D (1999) The role of the hospital environment in the epidemiology of multi-resistant bacteria. J Hosp Infect 43:13-17. https://doi.org/10.1053/jhin.1999.0613

[20] Madigan MT, Martinko JM, Parker J (2003) Brock biology of microorganisms, 10th edn. Southern Illinois University, Carbondale

[21] Kramer A, Schwebke I, Kampf G (2006) How long do nosocomial pathogens persist on inanimate surfaces? A systematic review. BMC Infect Dis 6:1-8. https://doi.org/ 10.1186/1471-2334-6-130

[22] Weinstein RA, Hota B (2004) Contamination, disinfection, and cross-colonization: are hospital surfaces reservoirs for nosocomial infection? Clin Infect Dis 39:1182-1189. http s://doi.org/10.1086/424667

[23] Zsuzsanna Schelz JH (2010) Recent advances in research of antimicrobial effects of essential oils and plant derived 
compounds on bacteria. Ethnomedicine A Source Complement Ther 661:179-201

[24] Dancer SJ (2004) How do we assess hospital cleaning? A proposal for microbiological standards for surface hygiene in hospitals. J Hosp Infect 56:10-15. https://doi.org/10.10 16/j.jhin.2003.09.017

[25] Pinto MS, Mcgahan ME, Steiner WW, Priefer R (2011) The use of the pseudo-polyelectrolyte, poly(4-vinylphenol ), in multilayered films as an antimicrobial surface coating. Colloids Surfaces A Physicochem Eng Asp 377:182-186. h ttps://doi.org/10.1016/j.colsurfa.2010.12.038

[26] Griffith CJ, Cooper RA, Gilmore J et al (2000) An evaluation of hospital cleaning regimes and standards. J Hosp Infect 45:19-28. https://doi.org/10.1053/jhin.1999.0717

[27] Weber DJ, Rutala WA, Miller MB, Huslage K (2010) Role of hospital surfaces in the transmission of emerging health care- associated pathogens: norovirus, Clostridium difficile, and Acinetobacter species. Am J Infect Control 38:S25S33. https://doi.org/10.1016/j.ajic.2010.04.196

[28] Cozad A, Jones RD, Aam RM (2003) Disinfection and the prevention of infectious disease. Environ Cause Infect. $h$ ttps://doi.org/10.1067/mic.2003.49

[29] Otter JA, Yezli S, French GL (2011) The role played by contaminated surfaces in the transmission of nosocomial pathogens. Infect Control Hosp Epidemiol 32:687-699. h ttps://doi.org/10.1086/660363

[30] J.W. C, L. M, C.R. A, (2005) Biofilm in implant infections: its production and regulation. Int $\mathrm{J}$ Artif Organs 28:1062-1068

[31] Chen X, Lou W, Liu J et al (2019) A novel antimicrobial polymer efficiently treats multidrug-resistant MRSA-induced bloodstream infection. Biosci Rep. https://doi.org/10. 1042/BSR20192354

[32] Arias-Ortiz PM, del Calderón L, Castillo JS et al (2016) Risk factors for methicillin-resistant Staphylococcus aureus bacteremia: a multicenter matched case-control study. Biomedica 36:612-619. https://doi.org/10.7705/biomedica. v36i4.3193

[33] Bukharie HA (2010) Review article: A review of community-acquired methicillin-resistant Staphylococcus aureus for primary care physicians. J Family Community Med. h ttps://doi.org/10.4103/1319-1683.74320

[34] Foxley MA, Friedline AW, Jensen JM et al (2016) Efficacy of ampicillin against methicillin-resistant Staphylococcus aureus restored through synergy with branched poly(ethylenimine). J Antibiotics. https://doi.org/10.1038/ ja.2016.44

[35] Dhanalakshmi TA (2012) Prevalence of inducible clindamycin resistance in Staphylococcus aureus. J Acad Med Sci 2:73-76. https://doi.org/10.4103/2249-4855.118664
[36] Kamaruzzaman NF, Firdessa R, Good L (2016) Bactericidal effects of polyhexamethylene biguanide against intracellular Staphylococcus aureus EMRSA-15 and USA 300. J Antimicrob Chemother 71:1252-1259. https://doi.org/10. 1093/jac/dkv474

[37] Dryden MS (2010) Complicated skin and soft tissue infection. J Antimicrob Chemother 65:35-44. https://doi. org/10.1093/jac/dkq302

[38] Grice EA, Segre JA (2011) The skin microbiome. Nat Rev Microbiol 9:244-253. https://doi.org/10.1038/nrmicro2537

[39] Singer AJ, Talan DA (2014) Management of skin abscesses in the era of methicillin-resistant Staphylococcus aureus. N Engl J Med 370:1039-1047. https://doi.org/10.1056/NE JMra1212788

[40] Cheng J, Chin W, Dong $\mathrm{H}$ et al (2015) Biodegradable antimicrobial polycarbonates with in vivo efficacy against multidrug-resistant MRSA systemic infection. Adv Healthc Mater. https://doi.org/10.1002/adhm.201500471

[41] Hebert C, Weber SG (2011) Common Approaches to the control of multidrug-resistant organisms other than methicillin-resistant Staphylococcus aureus (MRSA). Infect Dis Clin NA 25:181-200. https://doi.org/10.1016/j.idc.2010.11. 006

[42] Rutala WA, Weber DJ (2001) Surface disinfection: should we do it? J Hosp Infect 48:64-68

[43] Simo M (2010) A review of current and emergent biofilm control strategies. LWT Food Sci Technol 43:573-583. h ttps://doi.org/10.1016/j.lwt.2009.12.008

[44] Russell AD (1999) Bacterial resistance present knowledge to disinfectants: and future problems. J Hosp Infect 43:57-68

[45] Peng R, Luo Y, Cui Q et al (2020) Near-infrared conjugated oligomer for effective killing of bacterial through combination of photodynamic and photothermal treatment. ACS Appl Bio Mater 3:1305-1311. https://doi.org/10.1021/acsa bm. 9 b01242

[46] Zeng M, Xu J, Luo Q et al (2020) Constructing antibacterial polymer nanocapsules based on pyridine quaternary ammonium salt. Mater Sci Eng C 108:110383. https://doi. org/10.1016/j.msec.2019.110383

[47] Han J, Chen Q, Shen Y et al (2020) Click-chemistry approach toward antibacterial and degradable hybrid hydrogels based on octa-betaine ester polyhedral oligomeric silsesquioxane. Biomacromol 21:3512-3522. http s://doi.org/10.1021/acs.biomac.0c00530

[48] Mansouri J, Truong VK, MacLaughlin S et al (2019) Polymerization-induced phase segregation and self-assembly of siloxane additives to provide thermoset coatings with a defined surface topology and biocidal and self-cleaning 
properties. Nanomaterials 9:1-19. https://doi.org/10.3390/ nano9111610

[49] He J, Shi M, Liang Y, Guo B (2020) Conductive adhesive self-healing nanocomposite hydrogel wound dressing for photothermal therapy of infected full-thickness skin wounds. Chem Eng J 394:124888. https://doi.org/10.1016/ j.cej.2020.124888

[50] Liang Y, Chen B, Li M et al (2020) Injectable antimicrobial conductive hydrogels for wound disinfection and infectious wound healing. Biomacromol 21:1841-1852. https://doi.o rg/10.1021/acs.biomac.9b01732

[51] Zhang B, He J, Shi M et al (2020) Injectable self-healing supramolecular hydrogels with conductivity and photothermal antibacterial activity to enhance complete skin regeneration. Chem Eng J 400:125994. https://doi.org/10. 1016/j.cej.2020.125994

[52] Zhao X, Liang Y, Huang Y et al (2020) Physical doublenetwork hydrogel adhesives with rapid shape adaptability, fast self-healing, antioxidant and $\mathrm{NIR} / \mathrm{pH}$ stimulus-responsiveness for multidrug-resistant bacterial infection and removable wound dressing. Adv Funct Mater 30:1-18. h ttps://doi.org/10.1002/adfm.201910748

[53] Mercer DK, Katvars LK, Hewitt F et al (2017) NP108, an antimicrobial polymer with activity against methicillin and mupirocin resistant Staphylococcus aureus. Antimicrob Agent. https://doi.org/10.1128/AAC.00502-17

[54] Lienkamp K, Madkour AE, Kumar KN et al (2009) Antimicrobial polymers prepared by ring-opening metathesis polymerization: manipulating antimicrobial properties by organic counterion and charge density variation. Chem - A Eur J 15:11715-11722. https://doi.org/10. 1002/chem.200900606

[55] Madkour AE, Tew GN (2008) Towards self-sterilizing medical devices: controlling infection 10:6-10. https://doi. org/10.1002/pi.2399

[56] Thoma LM, Boles BR, Kuroda K (2014) Cationic methacrylate polymers as topical antimicrobial agents against Staphylococcus aureus nasal colonization. Biomacromol 15:2933-2943. https://doi.org/10.1021/b m500557d

[57] Engler AC, Wiradharma N, Ong ZY et al (2012) Emerging trends in macromolecular antimicrobials to fight multidrug-resistant infections. Nano Today 7:201-222. https://d oi.org/10.1016/j.nantod.2012.04.003

[58] Kuroda K, Caputo GA (2013) Antimicrobial polymers as synthetic mimics of host-defense peptides. Wiley Interdiscip Rev Nanomed Nanobiotechnol 5:49-66. https://doi.org/ 10.1002/wnan.1199
[59] Li P, Li X, Saravanan R et al (2012) Antimicrobial macromolecules: synthesis methods and future applications. RSC Adv. https://doi.org/10.1039/c2ra01297a

[60] Muñoz-Bonilla A, Fernández-García M (2012) Polymeric materials with antimicrobial activity. Prog Polym Sci 37:281-339. https://doi.org/10.1016/j.progpolymsci.2011.0 8.005

[61] Peng ZX, Wang L, Du L et al (2010) Adjustment of the antibacterial activity and biocompatibility of hydroxypropyltrimethyl ammonium chloride chitosan by varying the degree of substitution of quaternary ammonium. Carbohydr Polym 81:275-283. https://doi.org/10.1016/j.carbp ol.2010.02.008

[62] Qin C, Xiao Q, Li H et al (2004) Calorimetric studies of the action of chitosan- $\mathrm{N}$-2-hydroxypropyl trimethyl ammonium chloride on the growth of microorganisms. Int J Biol Macromol 34:121-126. https://doi.org/10.1016/j.ijbiomac. 2004.03.009

[63] Chung YC, Chen CY (2008) Antibacterial characteristics and activity of acid-soluble chitosan. Bioresour Technol 99:2806-2814. https://doi.org/10.1016/j.biortech.2007.06. 044

[64] Chin W, Yang C, Ng VWL et al (2013) Biodegradable broad-spectrum antimicrobial polycarbonates: Investigating the role of chemical structure on activity and selectivity. Macromolecules 46:8797-8807. https://doi.org/10.1021/ma 4019685

[65] Nederberg F, Zhang Y, Tan JPK et al (2011) Biodegradable nanostructures with selective lysis of microbial membranes. Nat Chem 3:409-414. https://doi.org/10.1038/nchem.1012

[66] Qiao Y, Yang C, Coady DJ et al (2012) Highly dynamic biodegradable micelles capable of lysing gram-positive and gram-negative bacterial membrane. Biomaterials 33:1146-1153. https://doi.org/10.1016/j.biomaterials.2011. 10.020

[67] Coles MP (2009) Bicyclic-guanidines, -guanidinates and guanidinium salts: wide ranging applications from a simple family of molecules. Chem Commun. https://doi.org/10.1 039/b901940e

[68] Sambhy V, Peterson BR, Sen A (2008) Antibacterial and hemolytic activities of pyridinium polymers as a function of the spatial relationship between the positive charge and the pendant alkyl tail. Angew Chemie Int Ed 47:1250-1254. h ttps://doi.org/10.1002/anie.200702287

[69] Testing S (2013) M100-S23 Performance Standards for Antimicrobial

[70] Uppu DS, Bhowmik M, Samaddar S, Haldar J (2016) Cyclization and unsaturation rather than isomerisation of side chains govern the selective antibacterial activity of 
cationic-amphiphilic polymers. Chemical Commun. 52(25):4644-4647. https://doi.org/10.1039/C5CC09930G

[71] Gabriel GJ, Madkour AE, Dabkowski JM et al (2008) Synthetic mimic of antimicrobial peptide with nonmembrane-disrupting antibacterial properties. Biomacromol 9:2980-2983. https://doi.org/10.1021/bm800855t

[72] Uppu DS, Akkapeddi P, Manjunath GB, Yarlagadda V, Hoque J, Haldar J (2013) Polymers with tunable side-chain amphiphilicity as non-hemolytic antibacterial agents. Chem Commun 49(82):9389-9391. https://doi.org/10.1039/c3cc 43751e

[73] Choi H, Chakraborty S, Liu R et al (2014) Medium effects on minimum inhibitory concentrations of nylon-3 polymers against E. coli. PLoS ONE. https://doi.org/10.1371/journal. pone. 0104500

[74] Li Z, a Pei Lin Cheea, Cally Owha RL and XJL, (2016) Safe and efficient membrane permeabilizing polymers based on PLLA for antibacterial applications. R Soc Chem. https://doi.org/10.1039/C6RA04531F

[75] Liu F, Hu J, Liu G et al (2014) Emulsion and nanocapsules of ternary graft copolymers. Polym Chem 5:1381-1392. h ttps://doi.org/10.1039/c3py01316b

[76] Zhang X, Tan BH, He C (2013) Tailoring the LCST of PNIPAAM- $b$-PLA- $b$-PNIPAAM triblock copolymers via stereocomplexation. Macromol Rapid Commun 34(22):1761-1766

[77] Wu X, He X, Zhong L et al (2011) Water-soluble dendriticlinear triblock copolymer-modified magnetic nanoparticles: preparation, characterization and drug release properties. J Mater Chem 21:13611-13620. https://doi.org/10.1039/c $1 \mathrm{jm} 11613 \mathrm{~d}$

[78] Yan S, Chen S, Gou X, Yang J, An J, Jin X, Yang YW, Chen L, Gao H (2019) Biodegradable supramolecular materials based on cationic polyaspartamides and Pillar [5] arene for targeting gram-positive bacteria and mitigating antimicrobial resistance. $\mathrm{Adv}$ Funct Mater. 29(38):1904683. https://doi.org/10.1002/adfm.201904683

[79] Ogoshi T, Kanai S, Fujinami S, Yamagishi TA, Nakamoto Y (2008) para-Bridged symmetrical pillar [5] arenes: their Lewis acid catalyzed synthesis and host-guest property. J Am Chem Soc. 130(15):5022-5023

[80] Yang Y, He P, Wang Y et al (2017) Supramolecular radical anions triggered by bacteria in situ for selective photothermal therapy. Angew Chemie 129:16457-16460. http s://doi.org/10.1002/ange.201708971

[81] Itaka K, Ishii T, Hasegawa Y, Kataoka K (2010) Biodegradable polyamino acid-based polycations as safe and effective gene carrier minimizing cumulative toxicity. Biomaterials 31:3707-3714. https://doi.org/10.1016/j.biom aterials.2009.11.072
[82] Yuen JWM, Chung TWK, Loke AY (2015) Methicillinresistant Staphylococcus aureus (MRSA) contamination in bedside surfaces of a hospital ward and the potential effectiveness of enhanced disinfection with an antimicrobial polymer surfactant. Int J Environ Res Public Health 12:3026-3041. https://doi.org/10.3390/ijerph120303026

[83] Yuen YWM, Yung J (2013) Medical implications of antimicrobial coating polymers-organosilicon quaternary ammonium chloride. Mod Chem Appl 1:1-4. https://doi. org/10.4172/2329-6798.1000107

[84] Wan KA, Ng MY, Wong YT (2011) New horizon on community-acquired methicillin resistant Staphylococcus aureus (CA-MRSA) skin and soft tissue infection: nanotechnology antimicrobial spray. Hong Kong J Emerg Med. 18(6):432-436. https://doi.org/10.1177/ 102490791101800611

[85] Boyce JM (2007) Environmental contamination makes an important contribution to hospital infection. J Hosp Infect 65:50-54. https://doi.org/10.1016/S0195-6701(07)60015-2

[86] Zhou Z, Wei D, Guan Y et al (2011) Extensive in vitro activity of guanidine hydrochloride polymer analogs against antibiotics-resistant clinically isolated strains. Mater Sci Eng C 31:1836-1843. https://doi.org/10.1016/j.msec. 2011.08.015

[87] Sun S, An Q, Li X et al (2010) Synergistic effects of chitosan-guanidine complexes on enhancing antimicrobial activity and wet-strength of paper. Bioresour Technol 101:5693-5700. https://doi.org/10.1016/j.biortech.2010.02. 046

[88] Guan Y, Qian L, Xiao H, Zheng A (2008) Preparation of novel antimicrobial-modified starch and its adsorption on cellulose fibers: Part I. Optimization of synthetic conditions and antimicrobial activities. Cellulose 15:609-618. https://d oi.org/10.1007/s10570-008-9208-6

[89] Palermo EF, Vemparala S, Kuroda K (2012) Cationic spacer arm design strategy for control of antimicrobial activity and conformation of amphiphilic methacrylate random copolymers. Biomacromol 13:1632-1641. https://d oi.org/10.1021/bm300342u

[90] Ishitake K, Satoh K, Kamigaito M, Okamoto Y (2009) Stereogradient polymers formed by controlled/living radical polymerization of bulky methacrylate monomers. Angew Chemie Int Ed 48:1991-1994. https://doi.org/10. 1002/anie.200805168

[91] McCoy CP, O’Neil EJ, Cowley JF et al (2014) Photodynamic antimicrobial polymers for infection control. PLoS ONE 9:1-11. https://doi.org/10.1371/journal.pone.0108500

[92] Wilson BC, Patterson MS (2008) The physics, biophysics and technology of photodynamic therapy. Phys Med Biol. h ttps://doi.org/10.1088/0031-9155/53/9/R01 
[93] Hamblin MR, O'Donnell DA, Murthy N et al (2002) Polycationic photosensitizer conjugates: Effects of chain length and Gram classification on the photodynamic inactivation of bacteria. J Antimicrob Chemother 49:941-951. https://doi.org/10.1093/jac/dkf053

[94] Labena A, Kabel KI, Farag RK (2016) One-pot synthesize of dendritic hyperbranched PAMAM and assessment as a broad spectrum antimicrobial agent and anti-biofilm. Mater Sci Eng C 58:1150-1159. https://doi.org/10.1016/j.msec.2 015.09 .042

[95] Hoovers J, Comanita B (1999) Dendrimers and dendrimerpolymer hybrids. Adv Polym Sci 142:179-228. https://doi. org/10.1007/3-540-68310-0_4

[96] Slany M, Bardaji M, Casanove MJ, Caminade AM, Majoral JP, Chaudret B (1995) Dendrimer surface chemistry. Facile route to polyphosphines and their gold complexes. J Am Chem Soc 117(38):9764-9765. https://doi.org/10.1021/ja0 $0143 \mathrm{a} 023$

[97] Cao L, Yang W, Wang C, Fu S (2007) Synthesis and striking fluorescence properties of hyperbranched poly(amido amine). J Macromol Sci Part A Pure Appl Chem 44(4):417-424. https://doi.org/10.1080/ 10601320601188299

[98] Nimmagadda A, Liu X, Teng P et al (2016) Polycarbonates with potent and selective antimicrobial activity toward gram-positive bacteria polycarbonates with potent and selective antimicrobial activity toward gram-positive. Biomacromol. https://doi.org/10.1021/acs.biomac.6b01385

[99] Li Y, Smith C, Wu H, Padhee S, Manoj N, Cardiello J, Qiao Q, Cao C, Yin HCJ (2014) Lipidated cyclic $\gamma$-AApeptides display both antimicrobial and anti-inflammatory activity. ACS Chem Biol. https://doi.org/10.1021/cb4006613

[100] Hoque J, Adhikary U, Yadav V et al (2016) Chitosan derivatives active against multidrug-resistant bacteria and pathogenic fungi. In vivo evaluation as topical antimicrobials. Mol Pharm 13:3578-3589. https://doi.org/10.1021/ac s.molpharmaceut.6b00764

[101] Kaminski K, Szczubialka K, Zazakowny K, Lach R, Nowakowska M (2010) Chitosan derivatives as novel potential heparin reversal agents. J Med Chem 53(10):4141-4147. https://doi.org/10.1021/jm1001666

[102] Cui D, Szarpak A, Pignot-Paintrand I et al (2010) Contactkilling polyelectrolyte microcapsules based on chitosan derivatives. Adv Funct Mater 20:3303-3312. https://doi.or g/10.1002/adfm.201000601

[103] Wiegand I, Hilpert K, Hancock REW (2008) Agar and broth dilution methods to determine the minimal inhibitory concentration (MIC) of antimicrobial substances. Nat Protoc 3:163-175. https://doi.org/10.1038/nprot.2007.521
[104] Moore K, Gray D (2007) Using PHMB antimicrobial to prevent wound infection. Wounds 3:96-102

[105] Firdessa R, Good L, Amstalden MC, Chindera K, Kamaruzzaman NF, Schultheis M, Röger B, Hecht N, Oelschlaeger TA, Meinel L, Lühmann T (2015) Pathogenand host-directed antileishmanial effects mediated by polyhexanide (PHMB). PLoS Negl Trop Dis 9(10):e0004041. https://doi.org/10.1371/journal.pntd. 0004041

[106] Cockerill F, Wikler M, Bush K, et al (2007) Performance standards for antimicrobial susceptibility testing; seventeenth informational supplement

[107] Hong S, Takahashi H, Nadres ET et al (2017) A cationic amphiphilic random copolymer with ph-responsive activity against methicillin-resistant Staphylococcus aureus. PLoS ONE 12:1-17. https://doi.org/10.1371/journal.pone. 0169262

[108] Takahashi H, Palermo EF, Yasuhara K et al (2013) Molecular design, structures, and activity of antimicrobial peptide-mimetic polymers. Macromol Biosci 13:1285-1299. https://doi.org/10.1002/mabi.201300126

[109] Schmid-Wendtner MH, Korting HC (2006) The pH of the skin surface and its impact on the barrier function. Skin Pharmacol Physiol 19:296-302. https://doi.org/10.1159/ 000094670

[110] Clinical and Laboratory Standards Institute (CLSI) (2015) M07-A10 Methods for dilution antimicrobial susceptibility tests for bacteria that grow aerobically; approved standard — tenth edition. Clin Infect Dis. https://doi.org/10.109 3/cid/ciw353

[111] Liu S, Ono RJ, Wu H et al (2017) Highly potent antimicrobial polyionenes with rapid killing kinetics, skin biocompatibility and in vivo bactericidal activity. Biomaterials 127:36-48. https://doi.org/10.1016/j.biomaterials.2017.02. 027

[112] Wee V, Ng L, Pang J et al (2014) Antimicrobial polycarbonates: investigating the impact of nitrogen- containing heterocycles as quaternizing agents. Macromolecules 47:1285-1291

[113] Hyldgaard M, Mygind T, Vad BS, Stenvang M, Otzen DE, Meyer RL (2014) The Antimicrobial mechanism of action of epsilon-poly-L-lysine. Appl Environ Microbiol 80(24):7758-7770. https://doi.org/10.1128/AEM.02204-14

[114] Hamano Y (2011) Occurrence, biosynthesis, biodegradation, and industrial and medical applications of a naturally occurring e-poly-L-lysine. Biosci Biotechnol Biochem 75:1226-1233. https://doi.org/10.1271/bbb.110201

[115] Chin W, Zhong G, Pu Q et al (2018) A macromolecular approach to eradicate multidrug resistant bacterial 
infections while mitigating drug resistance onset. Nat Commun 9:1-14. https://doi.org/10.1038/s41467-018-033 25-6

[116] Engler AC, Tan JPK, Ong ZY et al (2013) Antimicrobial polycarbonates: Investigating the impact of balancing charge and hydrophobicity using a same-centered polymer approach. Biomacromol 14:4331-4339. https://doi.org/10. 1021/bm401248t

[117] Pratt RC, Nederberg F, Waymouth M, Hedrick JL (2008) Tagging alcohols with cyclic carbonate: a versatile equivalent of (meth) acrylate for ring-opening polymerization. Chem Commun 2:114-116. https://doi.org/10.1039/b $713925 \mathrm{j}$

[118] Pratt RC, Lohmeijer BG, Long DA, Lundberg PP, Dove AP, Li H, Wade CG, Waymouth RM, Hedrick JL (2006) Exploration, optimization, and application of supramolecular thiourea-amine catalysts for the synthesis of lactide (co) polymers. Macromolecules 39(23):7863-7871

[119] Damavandi M, Pilkington LI, Whitehead KA et al (2018) Poly(para-phenylene ethynylene) (PPE)- and poly(paraphenylene vinylene) (PPV)-poly[(2-(methacryloyloxy)ethyl) trimethylammonium chloride] (PMETAC) graft copolymers exhibit selective antimicrobial activity. Eur Polym J 98:368-374. https://doi.org/10.1016/j.eurpolymj.2 017.11 .044

[120] Matyjaszewski K, Tsarevsky NV (2014) Macromolecular engineering by atom transfer radical polymerization. J Am Chem Soc 136:6513-6533. https://doi.org/10.1021/ja $408069 \mathrm{v}$

[121] Pintauer T, Matyjaszewski K (2008) Atom transfer radical addition and polymerization reactions catalyzed by $\mathrm{ppm}$ amounts of copper complexes. Chem Soc Rev 37:1087-1097. https://doi.org/10.1039/b714578k

[122] Lou W, Venkataraman S, Zhong G, Ding B, Tan JP, Xu L, Fan W, Yang YY (2018) Antimicrobial polymers as therapeutics for treatment of multidrug-resistant Klebsiella pneumoniae lung infection. Acta Biomater 78:78-88. http s://doi.org/10.1016/j.actbio.2018.07.038

[123] Zhong G, Cheng J, Liang ZC, Xu L, Lou W, Bao C, Ong ZY, Dong H, Yang YY, Fan W (2017) Short synthetic $\beta$ sheet antimicrobial peptides for the treatment of multidrugresistant Pseudomonas aeruginosa burn wound infections. Adv Healthc Mater 6(7):1601134

[124] Eren Boncu T, Uskudar Guclu A, Catma MF et al (2020) In vitro and in vivo evaluation of linezolid loaded electrospun PLGA and PLGA/PCL fiber mats for prophylaxis and treatment of MRSA induced prosthetic infections. Int J Pharm 573:118758. https://doi.org/10.1016/j.ijpharm.2019. 118758
[125] Pelipenko J, Kocbek P, Kristl J (2015) Critical attributes of nanofibers: preparation, drug loading, and tissue regeneration. Int J Pharm 484:57-74. https://doi.org/10.1016/j.ijpha rm.2015.02.043

[126] Li WJ, Laurencin CT, Caterson EJ, Tuan RS, Ko FK (2002) Electrospun nanofibrous structure: a novel scaffold for tissue engineering. J Biomed Mater Res 60(4):613-621

[127] Kuroki A, Kengmo Tchoupa A, Hartlieb M et al (2019) Targeting intracellular, multi-drug resistant Staphylococcus aureus with guanidinium polymers by elucidating the structure-activity relationship. Biomaterials 217:119249. h ttps://doi.org/10.1016/j.biomaterials.2019.119249

[128] Perrier S (2017) 50th anniversary perspective: RAFT polymerization: a user guide. Macromolecules 50(19):7433-7447. https://doi.org/10.1021/acs.macromol.7 b00767

[129] Moad G, Rizzardo E, Thang SH (2012) Living radical polymerization by the RAFT process a third update. Aust J Chem 65:985-1076. https://doi.org/10.1071/CH12295

[130] Kuroki A, Martinez-Botella I, Hornung CH, Martin L, Williams EG, Locock KE, Hartlieb M, Perrier S (2017) Looped flow RAFT polymerization for multiblock copolymer synthesis. Polym Chem 8(21):3249-3254. http s://doi.org/10.1039/C7PY00630F

[131] Guo L, Yan S, Tao X et al (2020) Evaluation of hypocrellin A-loaded lipase sensitive polymer micelles for intervening methicillin-resistant Staphylococcus aureus antibiotic-resistant bacterial infection. Mater Sci Eng C 106:110230. h ttps://doi.org/10.1016/j.msec.2019.110230

[132] Hu Y, Zhang L, Cao Y, Ge H, Jiang X, Yang C (2004) Degradation behavior of poly( $\varepsilon$-caprolactone)- $b$-poly(ethylene glycol)- $b$-poly( $\varepsilon$-caprolactone) micelles in aqueous solution. Biomacromol 5(5):1756-1762

[133] Huynh DP, Nguyen MK, Lee DS (2010) Controlling the degradation of $\mathrm{pH} /$ temperature-sensitive injectable hydrogels based on poly( $\beta$-amino ester). Mol Res 18:192-199. h ttps://doi.org/10.1007/s13233-009-0182-0

[134] Hyun H, Kim YH, Song IB et al (2007) In vitro and in vivo release of albumin using a biodegradable MPEG-PCL diblock copolymer as an in situ gel-forming carrier. Biomacromol 8:1093-1100. https://doi.org/10.1021/b m060991u

[135] Christofferson AJ, Elbourne A, Cheeseman S et al (2020) Conformationally tuned antibacterial oligomers target the peptidoglycan of gram-positive bacteria. J Colloid Interface Sci 580:850-862. https://doi.org/10.1016/j.jcis.2020.07. 090

[136] Barbon SM, Truong NP, Elliott AG et al (2019) Elucidating the effect of sequence and degree of polymerization on 
antimicrobial properties for block copolymers. Polym Chem 11:84-90. https://doi.org/10.1039/c9py01435g

[137] Ding X, Yang C, Peng T et al (2012) Biomaterials Antibacterial and antifouling catheter coatings using surface grafted PEG- $b$-cationic polycarbonate diblock copolymers. Biomaterials 33:6593-6603. https://doi.org/1 0.1016/j.biomaterials.2012.06.001

[138] Nejadnik MR, Van Der MHC, Norde W, Busscher HJ (2008) Bacterial adhesion and growth on a polymer brushcoating. Biomaterials 29:4117-4121. https://doi.org/10.10 16/j.biomaterials.2008.07.014

[139] Lee H, Dellatore SM, Miller WM (2007) Mussel-inspired surface chemistry for multifunctional coatings. Science 318:426-431. https://doi.org/10.1126/science.1149504

[140] Kamber NE, Jeong W, Waymouth RM et al (2007) Organocatalytic ring-opening polymerization. Chem Rev 107:5813-5840. https://doi.org/10.1021/cr068415b

[141] Kaur S, Harjai K, Chhibber S (2014) Local delivery of linezolid from poly-D,L-lactide (PDLLA )- linezolid-coated orthopaedic implants to prevent MRSA mediated postarthroplasty infections. Diagn Microbiol Infect Dis 43300:1-6. https://doi.org/10.1016/j.diagmicrobio.2014.01. 026

[142] Gollwitzer H, Ibrahim K, Meyer H et al (2003) Antibacterial poly(D,L-lactic acid) coating of medical implants using a biodegradable drug delivery technology. J Antimicrob Chemother. https://doi.org/10.1093/jac/dkg105

[143] Lee H, Park H, Kim K et al (2011) Effect of garlic on bacterial biofilm formation on orthodontic wire. Angle Orthonist. https://doi.org/10.2319/121010-713.1

[144] McMillan D, Lutton C, Rosenzweig N, Sriprakash KS, Goss B, Stemberger M, Schuetz M, Steck R (2011) Prevention of Staphylococcus aureus biofilm formation on metallic surgical implants via controlled release of gentamicin. J Biomed Sci Eng 4(8):535-542. https://doi. org/10.4236/jbise.2011.48069

[145] Dinjaski N, Fernández-gutiérrez M, Selvam S et al (2013) Biomaterials PHACOS, a functionalized bacterial polyester with bactericidal activity against methicillin-resistant Staphylococcus aureus. Biomaterials. https://doi.org/10.1016/ j.biomaterials.2013.09.059

[146] Escapa IF, Morales V, Martino VP, Pollet E, Avérous L, García JL, Prieto MA (2011) Disruption of $\beta$-oxidation pathway in Pseudomonas putida KT2442 to produce new functionalized PHAs with thioester groups. Appl Microbiol Biotechnol 89(5):1583-1598. https://doi.org/10.1007/s002 53-011-3099-4

[147] Moscoso M, García E, López R (2006) Biofilm formation by Streptococcus pneumoniae: role of choline, extracellular DNA, and capsular polysaccharide in microbial accretion. J Bacteriol 188(22):7785-7795. https://doi.org/10.1128/JB. 00673-06

[148] Weintraub S, Harris LG, Thevissen K, Lewitus DY (2018) Materialia polyastaxanthin-based coatings reduce bacterial colonization in vivo. Materialia 3:15-20. https://doi.org/10. 1016/j.mtla.2018.10.002

[149] Weintraub S, Shpigel T, Harris LG et al (2017) Astaxanthin-based polymers as new antimicrobial compounds. Polym Chem 8:4182-4189. https://doi.org/10.1039/c 7py00663b

[150] Kou PM, Pallassana N, Bowden R et al (2012) Predicting biomaterial property-dendritic cell phenotype relationships from the multivariate analysis of responses to polymethacrylates. Biomaterials 33:1699-1713. https://doi.org/ 10.1016/j.biomaterials.2011.10.066

Publisher's Note Springer Nature remains neutral with regard to jurisdictional claims in published maps and institutional affiliations. 